\title{
Intramedullary non-dysraphic cervical spine lipoma - Case report
}

\author{
Halisson Yoshinari Ferreira da Cruz ${ }^{1}$ Dhiego Bastos ${ }^{1}$, Andrei \\ Fernandes Joaquim², Enrico Ghizoni², Helder Tedeschi ${ }^{3}$ \\ University of Campinas (Unicamp), Campinas, SP, Brazil.
}

\section{ABSTRACT}

Intramedullary lipomas correspond to about $1 \%$ of the intramedullary tumors. These lesions are commonly associated with spinal dysraphisms and midline defects. Non-dysraphic lipomas are quite rare lesions, potentially located at any site of the spinal cord. Here we present the case history of an intramedullary non-dysraphic cervical spine lipoma.

\section{KEYWORDS}

Lipoma, spinal cord neoplasms, cervical vertebrae.

\section{RESUMO}

Lipoma intramedular da coluna cervical não disráfica - Relato de caso

Lipomas intramedulares correspondem a aproximadamente $1 \%$ dos tumores intramedulares. Essas lesões são comumente associadas com disrafismos e defeitos da linha média. Lipomas não disráficos são lesões muito raras, potencialmente localizadas em qualquer local da medula espinhal. Neste trabalho apresentamos o caso de um lipoma intramedular da coluna cervical não disráfica.

\section{PALAVRAS-CHAVE}

Lipoma, neoplasias da medula espinal, vértebras cervicais. 


\section{Introduction}

Intramedullary lipomas correspond to about $1 \%$ of the intramedullary tumors. ${ }^{1-4}$ These lesions are commonly associated with spinal dysraphisms and midline defects. Non-dysraphic lipomas are quite rare lesions, potentially located at any site of the spinal cord. ${ }^{5}$ Here we present the case history of an intramedullary non-dysraphic cervical spine lipoma.

\section{Case report}

A fifty-eight-year-old man was referred to our institution with a history of eight years progressive reduction in the muscular strength of his inferior left limb. This weakness progressed to his superior left limb during the last two years. He had also complained of numbness in his four limbs and some difficulty with walking, but no history of pain, or paresthesia. There was no history of sphincter or sexual dysfunction. His past medical history included alcohol abuse and heavy smoking. On examination, a spastic tetraparesis was noted, with an upper limbs grade IV muscular strength and grade III in the lower limbs. Global hyperreflexia, bilateral positive Babinski sign, bilateral positive Trömner and Hoffman sign. He also had a four limbs decreased light touch and vibratory sensibility, worse in his left side, with proprioceptive impairment and sensory ataxia. Radiological investigation with a cervical Magnetic Resonance Image (MRI) (Figure 1) showed a cervical spinal cord compression secondary to an intradural, intramedullary lesion, located in the rear portion of the spinal cord, extending from $\mathrm{C} 3$ to $\mathrm{C} 7$. The lesion was hyperintense at $\mathrm{T} 1$ sequence, with signal suppression at the fat suppression sequence.

The patient underwent a C3-7 non expansible laminoplasty. A dura mater enlargement could be notice. After dural opening, an expansible dorsal yellow lesion could be clearly seen at the spinal cord, as shown in figure 2. A cleavage plan between this yellow fatty tissue and the spinal cord was not present, as expected. Some dorsal nerve roots were inside the lesion. Microsurgical debulking, using concomitant ultrasonic aspiration was performed, until the neural tissue could be seen figure 3. After dural closure, the laminae were replaced.

The patient was referred to the intensive care unit. Immediately after surgery, he sustained the same preoperative neurological status. After two days he developed a delirium, with full recovery in the following day, leaving the hospital on the fourth day after surgery. A postoperative computed tomography scan showed no signs of the intradural lesion. One month later, some neurological improvement was achieved, with partial recovery of his muscular strength and improvement in walking ability. In his six months follow up, the patient had a grade IV+ muscular strength on all four limbs with residual spasticity. No sensory recover was achieved, but he presented a steadier gait despite his sensory ataxia. The six months cervical MRI showed no signs of compression with only a hyperintense line on the dorsal surface of the medulla at $\mathrm{T} 1$ sequence, without signal suppression at the fat suppression sequence and no expansive lesion figure 4.

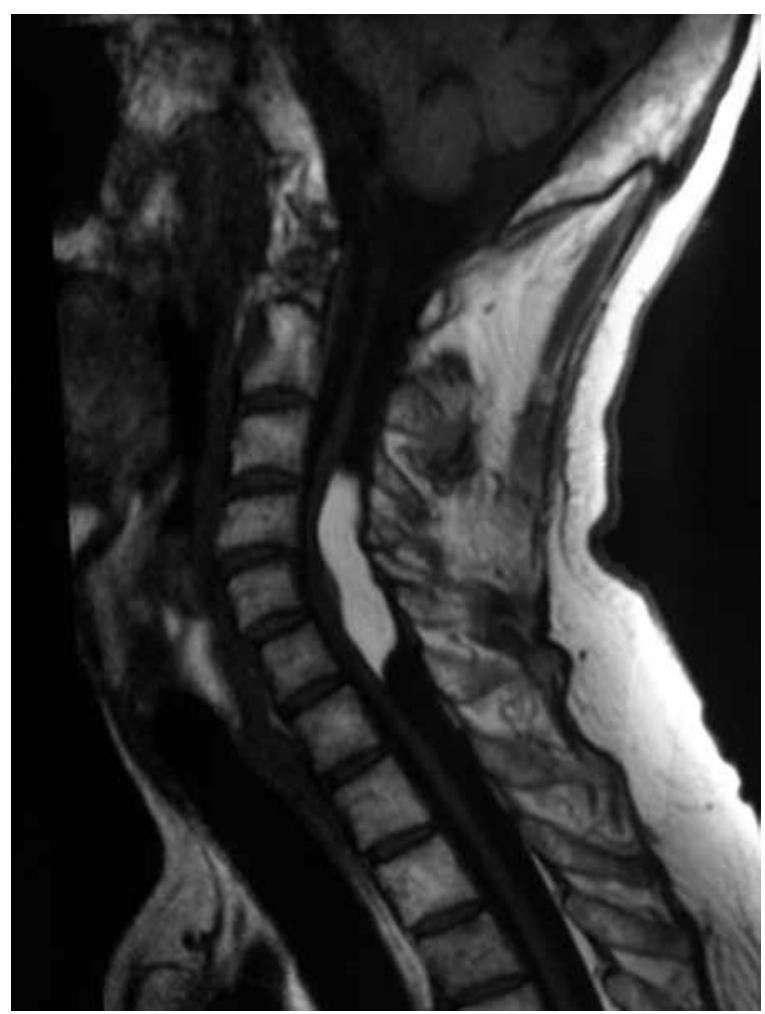

Figure 1 - Preoperative T1 sagittal MRI, showing a hyperintense lesion compressing the spinal cord.

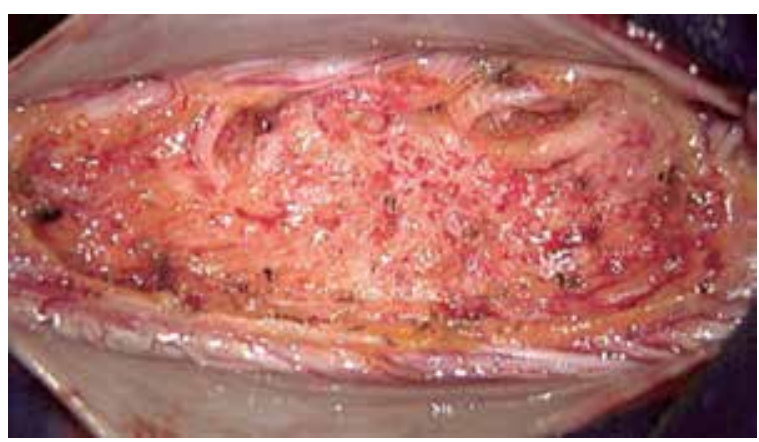

Figure 2 - An intraoperative picture showing a large fatty tissue mass in the dorsal portion of the spinal cord. 


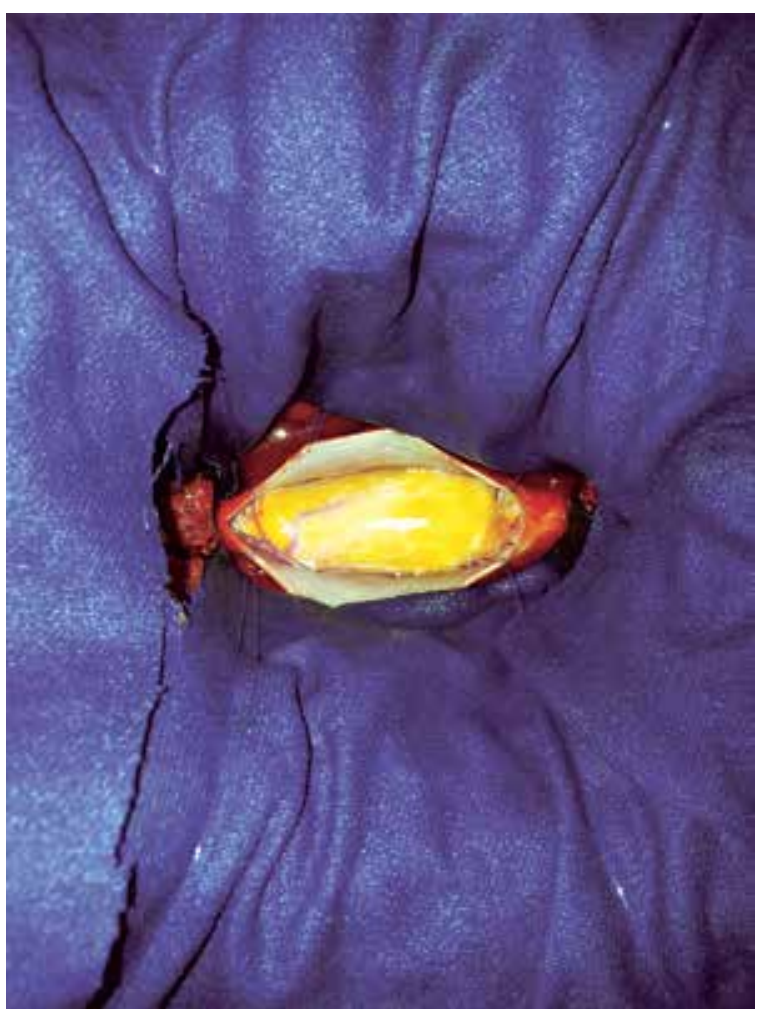

Figure 3 - An intraoperative picture showing the surgical site after lypoma debulking.

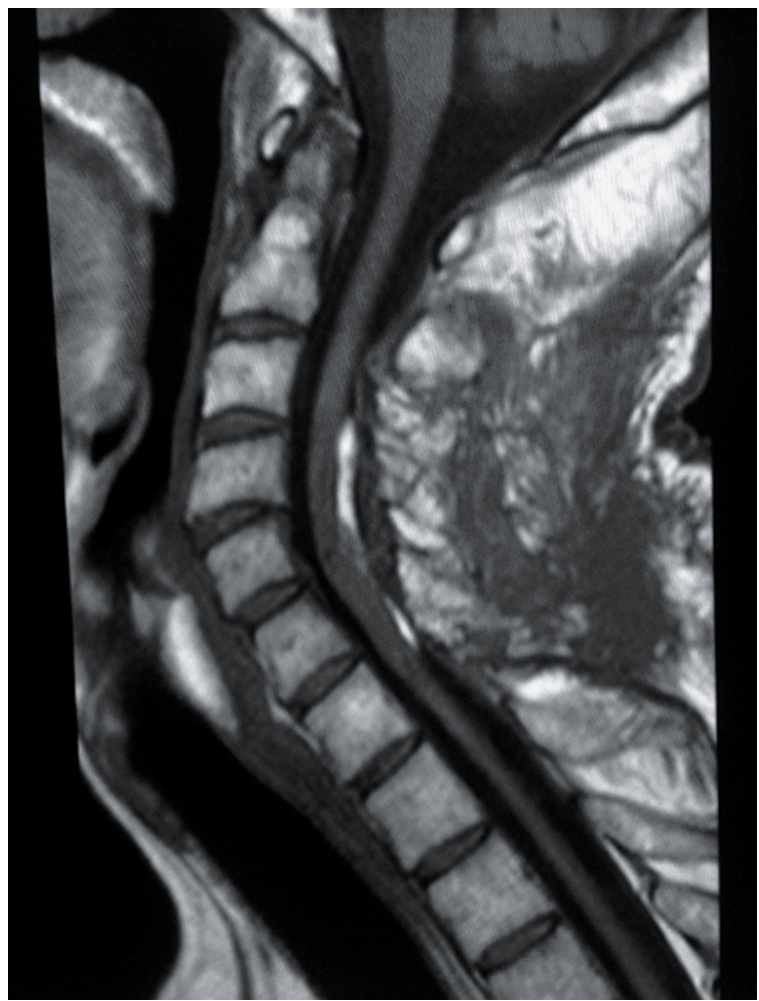

Figure 4 - Postoperative T1 sagittal MRI showing a residual hypersignal at the dorsal portion of the spinal cord, without compression.

\section{Discussion}

Non-dysraphic lipomas are essentially intradural lesions, without subcutaneous spreading, located in the dorsal portion of the spinal cord. Their incidence is about $0.45 \%-0.6 \%$ of all intramedullary tumors. ${ }^{1-5}$

Many theories have been proposed to explain their origin. Some authors considered them as hamartomas, because of their midline location and their same metabolic profile those normal adipocytes, suggesting a non neoplastic nature, although true lipomas had been reported. One of the theories to propose their origin is that a mistake in the mesenquimal cells migration inside the neural tube occurs, differentiating then in adipocytes. Another theory proposes that the mesenquimal cells that originate the vessels suffer metaplasia, resulting in adipocytes inside the neural tube. ${ }^{6,7}$

Regarding their location, although they can be found at any site of the spinal cord, the most common location is the thoracic spine. ${ }^{4}$ Histologically, they are a highly vascularized fatty tissue, most of them not true lipomas, but normal fatty tissue, strengthening the theory that they are hamartomas instead of real tumors, suffering the effects of gain or loss of weight.

Clinical presentation depends on its size and location, frequently with signs of progressive cord compression, with some relapse or worsening due to loss or gain of weight. The most common affect age is young adult, in the second decade of life. ${ }^{4}$

The diagnosis is based on MR findings, with a posterior intramedullary lesion hyperintense at $\mathrm{T} 1$ sequence, decrease signal intensity at T2 and suppressed sign intensity in the fat suppression techniques.

Surgical treatment is accepted in patients with cord compression. However, aggressive removal of the lesion can lead to a worsening of the neurological status. ${ }^{8}$ Some authors suggested that partial resection or dural expansion can improves outcomes. Surgery in asymptomatic patients is controversial, these patients or those with mild symptoms without neurological deficits can be followed clinically and radiologically; obese patients should be advised to lost weight. 9,10

The great surgical risk is associated to a lack of a clear cleavage plan between the fatty tissue and the spinal cord. A partial resection can stabilize the neurological status or even improve it.

Prognosis is closely related to preoperative neurological status. Motor deficits can have a better prognosis than sphincter dysfunction. Surgery options included laminectomy with duraplasty, partial resection or aggressive debulking. We believe that partial resection is safe and effective, as shown in our case. 


\section{Competing interests}

The authors declare no conflict of interest.

\section{References}

1. Akyuz M, Goksu E, Tuncer R. Spontaneous decrease in the size of a residual thoracic intradural lipoma. Br J Neurosurg. 2005;19(1):53-5.

2. Caram PC, Carton CA, Scarcella G. Intradural lipomas of the spinal cord; with particular emphasis on the intramedullary lipomas. J Neurosurg. 1957;14(1):28-42.

3. Ehni G, Love J. Intraspinal lipomas: report of cases; review of the literature, and clinical and pathologic study. J Nerv Ment Dis. 1945;102:520-1.

4. Giuffrè R. Intradural spinal lipomas. Review of the literature (99 cases) and report of an additional case. Acta Neurochir (Wien). 1966;14(1):69-95.
5. Bhatoe HS, Singh P, Chaturvedi A, Sahai K, Dutta V, Sahoo PK. Nondysraphic intramedullary spinal cord lipomas: a review. Neurosurg Focus. 2005;18(2):ECP1.

6. Rogers HM, Long DM, Chou SN, French LA. Lipomas of the spinal cord and cauda equina. J Neurosurg. 1971;34(3):349-54.

7. McCormick PC, Stein BM. Intramedullary tumors in adults. Neurosurg Clin N Am. 1990;1(3):609-30.

8. Lee M, Rezai AR, Abbott R, Coelho DH, Epstein FJ. Intramedullary spinal cord lipomas. J Neurosurg. 1995;82(3):394-400.

9. Razack N, Jimenez OF, Aldana P, Ragheb J. Intramedullary holocord lipoma in an athlete: case report. Neurosurgery. 1998;42(2):394-6.

10. Lunardi P, Missori P, Ferrante L, Fortuna A. Long-term results of surgical treatment of spinal lipomas. Report of 18 cases. Acta Neurochir (Wien). 1990;104(1-2):64-8.

\section{Correspondence address}

Halisson Yoshinari Ferreira da Cruz

Departamento de Neurologia

Cidade Universitária Zeferino Vaz, Barão Geraldo

13083-970 - Campinas, SP, Brazil

Telefax: (55 19) 35217905/Telefone: (55 19) 9118-5656

E-mail: halissonyoshinari@hotmail.com 